\title{
Language Learning Beliefs of Non-English Majors: Examining the Role of English Language Proficiency
}

\author{
Hadiseh Bagherzadeh \\ Department of English, Payame Noor University of Shabestar, Iran \\ Email: hadisehbagherzadeh@gmail.com
}

\begin{abstract}
This study investigates language learning beliefs of non-English majors with different levels of English language proficiency on language learning. The participants surveyed in this study were 125 (86 female and 39 male) Iranian non-English majors who were studying in biology, geography, accounting and science. Two instruments, i.e. the Michigan Language Proficiency Test (ECPE) and the translated version of Beliefs about Language Learning Inventory (BALLI) were administered to collect the required data sets. Statistical procedures used to analyze data revealed that proficiency level had a significant effect on the motivation of students. The more proficient participants reported holding strong beliefs in the category of "motivation and expectations". Also results indicate that there is a significant difference among the aptitude of the four groups of participants. The results obtained in this study also demonstrate that no statistical significance was observed between male and female non-English majors' beliefs in English language learning. The interaction between male and female students in these disciplines shows that these are significantly different in the foreign language aptitude and the nature of language learning.
\end{abstract}

Index Terms - learners' beliefs about language learning, beliefs about language learning, learning beliefs, language learning beliefs, beliefs, attitude

\section{INTRODUCTION}

Student centered learning received attention in recent years, when research interest in foreign language learning has shifted from teacher directed instruction to the learners' perspective, in which learner-related variables were examined. Beliefs of language learners about language learning, as one of these variables, demand more investigations. White (1999) stresses how awareness of the complexity of learner beliefs and expectations can help us to understand the realities of the early stages of self-instruction in language learners (cited in Hurd, 2003). Beliefs, according to Richardson (1996) are "psychologically held understandings, premises, or propositions about the world that are felt to be true" (cited in Bernat, 2006, p.2).

In the classroom context, the perceptions, beliefs, attitudes, and metacognitive knowledge that students bring to the learning situation have been recognized as a significant contributory factor in the learning process and ultimate success (Breen, 2001 cited in Bernat \& Gvozdenko, 2005). For example, in the context of second or foreign language learning, students may hold strong beliefs about the nature of the language under study, its relative difficulty, the process of its acquisition, the usefulness of various learning strategies, the existence of aptitude, the length of time it takes to acquire a foreign language, their own expectations about achievement and teaching methodologies. These beliefs influence the learners' attitudes to language and learning, their motivation and shape their experiences in the classroom. Consequently, they interrupt or promote the learners' ultimate success in the acquisition of a new language and diminish the length of time committed to language learning. As Bernat \& Gvozdenko (2005) claimed, identification of these beliefs and their reflection on their potential impact on language learning and teaching can inform future syllabuses design and teacher practice in the course.

The present study is an attempt to investigate the relationship between learning beliefs of non-English majors and their English language proficiency in language learning.

\section{REVIEW OF THE RELATED LITERATURE}

It is generally agreed that individual language learners hold different beliefs about how language is learned. Individual beliefs about language learning may consciously or unconsciously influence learners' approaches to language learning (Mokhtari, 2007). As Horwitz (1985, 1987 \& 1999) claimed, it is important to understand learner beliefs to better understand learner approaches to language learning, and learners' use of learning strategies to better plan language instruction (cited in Mokhtari, 2007).

Since the mid 1980s, a number of studies in second or foreign language learning were devoted to beliefs that language learners hold. Impetus for these studies was given by the pioneering research of Elaine Horwitz of the 
University of Texas at Austin. In 1980, Horwitz conducted her research among students and instructors by her designed instrument (BALLI) at the University of Texas at Austin. According to Nikitina \&Furuoka (2006), Park (1995) investigated beliefs of English language learners at two universities in Korea.

Victori and Lockhart (1995) discuss differences between " insightful beliefs" which successful learners hold, and the negative or limited beliefs" which poor learners hold, state that:

... if students develop or maintain misconceptions about their own learning, if they attribute undue importance to factors that are external to their own action... they are not likely to adopt a responsible and active attitude in their approach to learning and may never become autonomous (cited in Tercanlioglu, 2005, p.225).

\section{A. Classifications of Beliefs about Language Learning}

According to Mokhtari (2007), among researchers, Horwitz (1987) is considered the first researcher to attempt to identify language learners' beliefs in a systematic way. Based on free-recall tasks and focus group discussions with both foreign language and ESL teachers and students, she developed a 34 Likert-scale questionnaire, called the beliefs about language learning Inventory (BALLI) to identify student beliefs. The BALLI assesses students' beliefs in five major areas: (1) foreign language aptitude; (2) the difficulty of language learning; (3) the nature of language learning ;( 4) learning and communication strategies; and (5) motivation and expectations (Horwitz, 1987).The BALLI instrument has been employed in a number of subsequent studies (Tumposky, 1991; Yang, 1992; Kern, 1995; Park 1995; Truitt, 1995; Oh, 1996; Kuntz, 1996; Kuntz, 1996; Kunt, 1997; Kim-Yoon, 2000; Kim 2001; and Hong 2006) showing that various beliefs are widespread but also culture-bounded at least to an extent.

\section{B. Studies on Beliefs in an ESL Context}

Cotterall (1995) emphasized on determining learners' readiness for autonomy and explored the relationship between ESL learners' beliefs about language learning and their autonomous language learning behavior, i.e. their readiness for autonomy.

Breen (2001) investigated how learners' attributes such as beliefs, aptitude, personality, or the concept of identity affect their conceptions of themselves and the learning environment. The author asserts that learners work selectively within their learning environment, and upon the linguistics and communicative data made available to them in that environment. This selectively derives from the learners' conceptualizations of the conditions that they believe to be facilitating or hindering their learning and their conceptualizations of the language to be learned. He also points out that such conceptualizations are imbued with the learners' feelings and attitudes, leading to the conclusion that affect, inter alia, shape one's cognitive conceptualizations or beliefs (cited in Bernat \& Gvozdenko, 2005).

Successful learners develop insights into beliefs about the language learning processes and the use of affective learning strategies. Learners need to be aware of their beliefs and change their beliefs to make learning more effective.

147 Japanese learners were investigated in Lambert (2001) study by responding to questions concerning their beliefs and opinions about language learning. In order to determine their viability as input for L2 course design, the amount of agreement in learners' responses to 126 items concerning five major aspects of L2 courses was compared over a period of two weeks, and again over a period of one year. The findings showed that such knowledge might be used more productively in the classroom as a basis for dialogue between teachers and learners.

Another study by Bernat (2004) used BALLI to explore 20 adult Vietnamese ESL learner beliefs about language learning. The findings indicated that all of respondents (100\%) either strongly agreed or agreed the importance to repeat and practice the target language being acquired as well as better English proficiency was likely to bring greater job opportunities most of them (80\%) endorsed the importance of excellent pronunciations. Only 55\% learners agreed the statement "it is necessary to know about English speaking cultures to speak English" (cited in Chiou, 2006).

Conscious or not, beliefs about language learning may influence the way learners approach language learning and types of learning tasks that are likely to produce problems or difficulties instead of helping to achieve goals, as they build up misconceptions about language learning (Oz, 2007).

\section{Studies on Beliefs in an EFL Context}

The study of Sakui and Gaies (1999) with 1300 Japanese EFL learners at tertiary level on their communicative and traditional orientation to learning the quality and sufficiency of classroom instruction, and foreign Language aptitude and difficulty. They stated that the most learner beliefs correspond to the distinction between traditional and contemporary views of language teaching and learning, language aptitude and difficulty.

Tanaka's study (2004 cited in Ellis, 2008), investigated the relationship between beliefs and language proficiency in 132 Japanese learners of English divided into two groups:

The New Zealand Group_63 Japanese students studying English in an Auckland tertiary institute for 12 weeks.

The Japanese group_69 Japanese students who were studying English in a Japanese university in Tokyo.

Tanaka administrated the belief questionnaire consisting of 27 Likert scale items, interview, diary, oxford placement test and oral narrative task. According the findings, most of the students were very dissatisfied with their English proficiency at the beginning of the study, which they attributed to the poor English language education they had received in Japan. Tanaka found that overall the relationships between beliefs and proficiency measures were very weak The NZ Japanese students who reinforced their beliefs relating to experiential learning during study abroad tended to 
advance more in general proficiency but not in speaking ability. Changes in beliefs relating to analytic learning and affective states did not affect either general proficiency or speaking ability.

Zhang \& Zhou (2005) explored the relationship between language learners' beliefs and autonomous learning in the Chinese learning context so as to cultivate the students learning autonomy and self-awareness, to improve their learning efficiency and to solve the problem of "teaching students how to learn". It must be accepted that language learning and teaching is a part of the total educational process, which means the development of autonomy through students being given practice in decision-making and thus accepting responsibility for their own learning and gaining experience which enables them to learn a third or fourth language.

$\mathrm{Oz}$ (2007) investigated metacognitive knowledge or beliefs about language learning of 470 Turkish EFL learners in secondary education. The primary aims of his study were to explore what beliefs Turkish students in secondary education held about learning English as a foreign language (EFL), how their beliefs systems were organized and whether there were significant differences in belief systems among learner groups according to variables such as social and school contexts, gender, age and grade level. Structured questionnaire based on Horwitz's Beliefs About Language Learning Inventory (BALLI) (1987) used to collect required data sets. The results of this study showed that learners' metacognitive knowledge or beliefs about language learning have variability in terms of social and educational contexts, age, gender, and stages of language.

Bernat \& Lloyd (2007) investigated the relationship between beliefs about language learning and gender. The Beliefs About Language Learning Inventory (BALLI) and Wilcoxon-Mann-Whitney test administrated to 155 female and 107 male English as a Foreign Language students. Results show that overall males and females held similar beliefs about language learning, with only one item being statistically significant and another one being marginally significant.

Peacock (2007) conducted an investigation on the Links between learner beliefs, teacher beliefs, and EFL proficiency on 202 students in ten EFL classes and 45 teachers in the department of English, at the City University of Hong-Kong. The aim of this study was to carry out how far learner beliefs differ from those held by EFL teachers, whether those differences affect language learning (and in particular, whether incorrect beliefs are associated with lower proficiency levels), and how they might be eliminated. The initial set of data was collected using Horwitz BALLI (Beliefs about Language Learning Inventory BALLI). Further data were collected during learner interviews, a proficiency test, and from essays. An additional aim of the study was to develop hypothesis about the origins of Hong Kong learner beliefs about language learning. Two further beliefs about language learning were also investigated; first, learners were asked to self-rate proficiency, making it possible to check the correlation between learners self-rated proficiency and tested proficiency. Second, the 25 most proficient and the 25 least proficient learners were asked for their opinions on the best way to learn EFL, and answers compared.

It has become obvious, by examining scores for self-rated proficiency, that almost all the students researched have a rather low opinion of their own abilities. Most rated themselves 'fair' in all areas, and only 8 percent rated themselves 'good' (there were almost no differences by gender). Certainly these students' actual ability is better than they estimate; this (as did certain results from the BALLI) also indicates a degree of lack of confidence. Another interesting finding that emerged from the correlations between tested and self-rated proficiency is that for these learners, there was a significant difference by gender in skill at estimating (1) their overall ability, and (2) their ability in listening and in reading (though not in grammar or in writing). Females were considerably more skilled, or more honest, at this than males. Two possible reasons for the differences are that males were conspicuously worse than females at estimating, or conspicuously worse at admitting, their own strengths and weaknesses. The findings of this study suggest that teachers examine their learners' beliefs and do what they can to reduce learner misunderstanding and dissatisfaction.

Rieley (2009) study investigated the beliefs about English language learning of 661 first-year university students and their 34 English teachers at a Japanese university. The focus of the article is the shifts in reported student beliefs over a nine-month period of English study between two administrations of the Sakui and Gaies (1999) beliefs survey instrument. Beliefs are usually considered as resilient constructs, self-perpetuating in nature. In this study, however, significant differences were found in student responses to almost a quarter of the items on the questionnaire. Two student discussion groups were also formed which provided further evidence of shifts in student beliefs about language learning during the nine-month period of English study.

\section{Studies on Beliefs in an FL context}

Mantle-Bromley (1995) investigated the link between the beliefs and attitudes of Spanish and French learners and found that many young learners bring to the language classroom misconceptions or erroneous beliefs likely to impede their learning progress. Mantle-Bromley (1995) explained that learner with positive beliefs are more likely to perform better in class.

Horwitz (1988, cited in Mokhtari, 2007) conducted a study on American students of foreign languages. She administrated the BALLI to 241 foreign language students at the University of Texas at Austin. Three language learning groups; German, French, and Spanish were used for comparison. Horwitz found a similarity of beliefs among the different target language groups; the findings did not reveal statistically significant differences in beliefs. However, the responses indicated several small differences in beliefs among the groups. Horwitz explained that" such small differences among groups could result from measurement error, Differences in populations, the special nature of learning the target language, or the instructional content of specific classes" (p.291). She argued that knowledge of 
learner beliefs may be useful to educators to understand how learners approach language learning. The findings may clarify some misconceptions about language learning which lead learners to use less effective strategies.

Kuntz (1996) explored the beliefs about language learning by 424 first-month university students enrolled in both commonly taught languages (French, German and Spanish) and less commonly taught languages (Arabic and Swahili), using BALLI. This study identified some learning beliefs that were significantly different between the two groups. Findings of this study provided strong evidence that the language studies do influence the beliefs of student's concerning foreign language learning. Students of Arabic and Swahili showed a preference for statements associated with communication strategies and people of the target language countries. According to Kuntz, the language in this study as well as culture and social environment may have shaped beliefs of students (cited in Nikitina \& Furuoka, 2007).

In another study, Kuntz (1999) investigated beliefs about language learning among schoolchildren of different languages (French, German, Latin, Spanish) at five levels of language instruction. Though the learners in her research were of much younger age than university students, the results provide some useful for the present study insights. Kuntz assessed beliefs that had been most commonly shared by the students of different languages at different levels of instruction as well as beliefs that had differed significantly between the groups of learners. She concluded that learners' assumptions about foreign language learning do change with the length of instruction, and some beliefs weaken while others grow stronger. Especially, beliefs concerning communication strategies underwent most significant changes. For example, Students of all languages at more advanced levels expressed stronger disagreement with the statements that learning a foreign language is mostly a matter of translation, and that one has to know all the words for a good reading comprehension. Also, the students acquired more realistic beliefs about time spending needed for learning a foreign language. Kuntz concludes that "these changes may reflect program activities and personal experiences" (cited in Nikitina \& Furuoka, 2007, p.33).

\section{METHOD}

\section{A. Participants}

The participants surveyed in this study were $125(\mathrm{~N}=125)$ Iranian non-English majors, both male and female. As indicated in Table 1, they were majoring in biology, geography, accounting and science. They were selected from among non-English majors studying for a B.A. degree at Azad University of Marand.

TABLE 1:

DISTRIBUTION OF PARTICIPANTS

\begin{tabular}{|c|c|c|c|c|}
\hline & & \multicolumn{2}{|c|}{ Sex of participants } & \multirow{2}{*}{ Total } \\
\hline & & Female & Male & \\
\hline \multirow{4}{*}{ Field of study } & biology & 29 & 9 & 38 \\
\hline & geography & 15 & 16 & 31 \\
\hline & accounting & 23 & 12 & 35 \\
\hline & science & 19 & 2 & 21 \\
\hline \multicolumn{2}{|l|}{ Total } & 86 & 39 & 125 \\
\hline
\end{tabular}

\section{B. Research Questions}

This study addresses the following research questions:

1. Is there any significant difference between language proficiency levels of non-English majors and their beliefs in English language learning?

2. Is there any significant difference between the field of study and non-English majors' beliefs in English language learning?

3. Is there any significant difference between male and female non-English majors' beliefs in English language learning?

\section{Instruments}

\section{The translated version of Beliefs about Language Learning Inventory (BALLI)}

The beliefs about Language Learning Inventory (BALLI) were developed by Horwitz (1987) to elicit learners' beliefs about language learning. It contains thirty-four items relating to beliefs within five major areas:

1. foreign language aptitude

2. the difficulty of language learning

3. the nature of language learning

4. learning and communication strategies, and

5. motivation and expectations

Since my participants were not highly proficient, the researcher used the translated version of belief questionnaire including thirty-two items. For any single question or item in the questionnaire, we need to argue for its construct. In other words, what does it test? As Table 2 shows, there is one construct for any bunch of statements or items in the belief questionnaire as follows: 
TABLE 2:

DISTRIBUTION OF THE ITEMS OF BELIEF QUESTIONNAIRE BASED ON THE CONSTRUCT

\begin{tabular}{|l|l|}
\hline Construct & Items \\
\hline foreign language aptitude & $1,2,5,9,10,14,17,28,31$ \\
\hline the difficulty of language learning & $3,23,32$, \\
\hline the nature of language learning & $7,11,15,21,25,26$ \\
\hline learning and communication strategies & $6,8,12,13,16,19,20,24$ \\
\hline motivation and expectations & $4,18,22,27,29,30$ \\
\hline
\end{tabular}

\section{The Michigan Language Proficiency Test}

From among the possible language proficiency tests (TOEFL, IELTS, Nelson Reading Checklist, and the University Michigan Language Proficiency Test (ECPE), a decision had to be made on one of these tests as an indicator of the readers' language proficiency. Given the fact the students' major was not English; it was assumed that TOEFL and IELTS might be very difficult. Moreover, Nelson Reading Checklist lacks reading comprehension section which is actually a major component of language proficiency. However, the Michigan test battery has some cloze passages which are considered to be good predictors of language proficiency. Therefore, it was supposed that the Michigan Language Proficiency Test may be a better candidate for the purposes of the present study.

The University of Michigan language proficiency test battery consisted of 70 items; 10 items constituted a cloze reading passage, 25 items tested knowledge of grammar, and 25 dealt with vocabulary. Also, this test included two reading comprehension passages each followed by five reading comprehension items. The test items were randomly selected from the University of Michigan ECPE test battery. The test was used to assign the participants to the three different proficiency levels of Low, Intermediate, and High.

\section{RESULTS}

This section is devoted to the analyses of data collected for the purpose of this study. The quantitative analysis of this study used the Statistical Package for Social Sciences (SPSS) version 16.0 for MS Windows XP.

\section{A. Descriptive Analysis of Michigan Test}

The result of descriptive analysis of Michigan test, as appeared in Table 3, shows that multiple-choice grammar has the highest mean and is more homogeneous. While reading comprehension has the lowest mean and is more heterogeneous.

TABLE 3:

DESCRIPTIVE ANALYSIS OF MiCHIGAN TEST

\begin{tabular}{|c|c|c|c|c|}
\hline \multicolumn{5}{|l|}{ Statistics } \\
\hline & Cloze grammar & Vocabulary & Reading comprehension & Multiple choice grammar \\
\hline $\mathbf{N}$ & 126 & $126^{\circ}$ & 125 & 126 \\
\hline Mean & 20.71 & 21.5238 & 19.4400 & 24.31 \\
\hline Std. Deviation & 13.27 & 9.39 & 14.15 & 9.07 \\
\hline
\end{tabular}

\section{B. Descriptive Analysis of Belief Questionnaire}

As indicated in Table 4, the results of descriptive analysis of belief questionnaire show that the highest mean belonged to the "motivation and expectations" category, while the lowest mean belonged to the "foreign language aptitude".

TABLE 4:

DESCRIPTIVE ANALYSIS OF BELIEF QUESTIONNAIRE

\begin{tabular}{|l|l|l|l|l|l|}
\hline & aptitude & difficulty & motivation & nature & communication strategies \\
\hline $\mathbf{N}$ & 115 & 120 & 77.0000 & 114 & 84.0351 \\
\hline Mean & 73.2560 & 12.54981 & 12.66367 & 107 & 111 \\
\hline Std. Deviation & 9.89409 & 81.1838 & 76.3514 \\
\hline
\end{tabular}

\section{Levels of Language Proficiency}

In order to classify participants into three groups (Low, Intermediate and High) their total scores were used.

In order to have a relatively similar number of participants in each level half of SD $(\mathrm{SD}=3.15)$ were added and subtracted from mean scores. Therefore, the low proficient group scored between 15.7 to18.85 and intermediate participants scored 18.86 to 25.15 and finally advance group scored 25.26 and higher. The distribution of the participants in each group according to their proficiency level appeared in Table 5. 
TABLE 5:

DISTRIBUTION OF PARTICIPANTS ACCORDING TO THEIR PROFICIENCY LEVEL

\begin{tabular}{|l|l|l|l|l|l|}
\hline \multicolumn{2}{|l|}{ proflevel } & Frequency & Percent & Valid Percent & Cumulative Percent \\
\hline \multirow{4}{*}{ Valid } & Low & 35 & 27.8 & 28.0 & 28.0 \\
\cline { 2 - 6 } & Intermediate & 54 & 42.9 & 43.2 & 71.2 \\
\cline { 2 - 6 } & High & 36 & 28.6 & 28.8 & 100.0 \\
\cline { 2 - 6 } & Total & $\mathbf{1 2 5}$ & $\mathbf{9 9 . 2}$ & $\mathbf{1 0 0 . 0}$ & \\
\hline Missing & System & $\mathbf{1}$ & $\mathbf{. 8}$ & & \\
\hline Total & $\mathbf{1 2 6}$ & $\mathbf{1 0 0 . 0}$ & & \\
\hline
\end{tabular}

\section{Descriptive Analyses of Sections of Belief Questionnaire}

\section{Aptitude}

In order to examine the views of participants on the items expected to examine the aptitude of participants on learning, a chi-square analysis was performed. As indicated in Table 6, the results show that the participants have more agreement on items b1, b2, and b31. The participants' view on items b1, b2, and b28 are more homogenous. The chisquare analysis shows that there is a significant difference among the responses of participants to these items.

TABLE 6:

DESCRIPTIVE STATISTICS OF ITEMS EXAMINING APTITUDE

\begin{tabular}{|c|c|c|c|c|c|c|c|}
\hline Items & Content & $\mathbf{N}$ & Mean & $\begin{array}{l}\text { Std. } \\
\text { Deviation }\end{array}$ & Chi-Square & df & $\begin{array}{l}\text { Asymp. } \\
\text { Sig. }\end{array}$ \\
\hline b1ap & It's easier for children than adults to learn a second language. & 126 & 4.6905 & .57221 & $1.734 \mathrm{E} 2^{\mathrm{a}}$ & 3 & .000 \\
\hline b2ap & Some people have a special ability for learning second language. & 124 & 4.3065 & .88508 & $1.189 \mathrm{E} 2^{\mathrm{b}}$ & 4 & .000 \\
\hline b5ap & $\begin{array}{l}\text { People in my country are very good at learning second } \\
\text { languages. }\end{array}$ & 124 & 3.2984 & 1.09678 & $34.952^{\mathrm{b}}$ & 4 & .000 \\
\hline b9ap & $\begin{array}{l}\text { It's easier for someone who already speaks a foreign language to } \\
\text { learn another one. }\end{array}$ & 126 & 3.5317 & 1.19121 & $25.508^{\mathrm{c}}$ & 4 & .000 \\
\hline b10ap & $\begin{array}{l}\text { People who are good at mathematics or science are not good at } \\
\text { learning foreign languages. }\end{array}$ & 125 & 2.3120 & 1.14593 & $38.160^{\mathrm{d}}$ & 4 & .000 \\
\hline b14ap & I have a special ability for learning foreign languages. & 123 & 3.2033 & 1.10853 & $49.154^{\mathrm{e}}$ & 4 & .000 \\
\hline b17ap & Women are better than men at learning foreign languages. & 124 & 3.3226 & 1.23991 & $40.677^{\mathrm{b}}$ & 4 & .000 \\
\hline b28ap & People who speak more than one language are very intelligent. & 122 & 3.9836 & .97898 & $72.262^{f}$ & 4 & .000 \\
\hline b31ap & Everyone can learn to speak a second language. & 122 & 4.2541 & 1.09515 & $122.344^{\mathrm{f}}$ & 4 & .000 \\
\hline
\end{tabular}

\section{Difficulty of language learning}

To investigate the views of participants on the items expected to examine the difficulty of participants on learning, a chi-square analysis was performed. The results, appeared in Table 7, show that the participants have more agreement on item $b 32$. The homogeneity of the views of participants on these items is relatively the same. The chi-square analysis shows that there is a significant difference among the responses of participants to these items.

TABLE 7:

DESCRIPTIVE STATISTICS OF ITEMS EXAMINING DIFFICULTY OF LANGUAGE LEARNING

\begin{tabular}{|l|l|l|l|l|l|l|l|}
\hline Items & Content & $\mathbf{N}$ & Mean & $\begin{array}{l}\text { Std. } \\
\text { Deviation }\end{array}$ & Chi-Square & $\begin{array}{l}\text { Asymp. } \\
\text { Sig. }\end{array}$ \\
\hline b3dif & Some languages are easier than others. & 126 & 3.9365 & 1.04878 & $61.540^{\mathrm{a}}$ & 4 & .000 \\
\hline b23dif & $\begin{array}{l}\text { It is easier to speak than understand a foreign } \\
\text { language. }\end{array}$ & 122 & 3.3770 & 1.20143 & $23.820^{\mathrm{b}}$ & 4 & .000 \\
\hline b32dif & $\begin{array}{l}\text { It is easier to read than to write a foreign } \\
\text { language. }\end{array}$ & 121 & 4.2149 & 1.03446 & $1.036 \mathrm{E} 2^{\mathrm{c}}$ & 4 & .000 \\
\hline
\end{tabular}

\section{Nature of language learning}

In order to examine the views of participants on the items expected to examine the nature of language learning of participants on learning, a chi-square analysis was performed. The results, appeared in Table 8 , shows that the participants have more agreement on items b11, b15, and b25. The participants' view on items b11, b15 are more homogenous. The chi-square analysis shows that there is a significant difference among the responses of participants to these items. 
TABLE 8:

DESCRIPTIVE STATISTICS OF ITEMS EXAMINING NATURE OF LANGUAGE LEARNING

\begin{tabular}{|l|l|l|l|l|l|}
\hline Items & Content & $\mathbf{N}$ & Mean & Std. Deviation & Chi-Square \\
\hline b7nat & $\begin{array}{l}\text { It is necessary to learn about English-speaking cultures } \\
\text { to speak English. }\end{array}$ & 121 & 3.7355 & 1.21634 & $34.826^{\mathrm{a}}$ \\
\hline Sig.
\end{tabular}

\section{Learning and communication Strategies}

To investigate the views of participants on the items expected to examine the learning and communication strategies of participants on learning, a chi-square analysis was performed. Table 9 shows that the participants have more agreement on items b6, b16, and b24. The participants' view on items b16, b24 are more homogenous. The chi-square analysis shows that there is a significant difference among the responses of participants to these items. However, as Table 9 shows, the views of participants on b8 are not statistically significant.

TABLE 9:

DESCRIPTIVE ANALYSIS OF ITEMS EXAMINING LEARNING AND COMMUNICATION STRATEGIES

\begin{tabular}{|c|c|c|c|c|c|c|c|}
\hline Items & Content & $\mathbf{N}$ & Mean & $\begin{array}{l}\text { Std. } \\
\text { Deviation }\end{array}$ & Chi-Square & df & Asymp. Sig. \\
\hline b6cs & $\begin{array}{l}\text { It is important to speak English with an excellent } \\
\text { pronunciation. }\end{array}$ & 122 & 4.3033 & 1.001 & $1.262 \mathrm{E} 2^{\mathrm{a}}$ & 4 & .000 \\
\hline b8cs & $\begin{array}{l}\text { You shouldn't say anything in English until you can say } \\
\text { it correctly. }\end{array}$ & 126 & 3.2619 & 1.47610 & $7.175^{\mathrm{b}}$ & 4 & .127 \\
\hline b12cs & I enjoy practicing English. & 125 & 3.5920 & 1.25142 & $36.160^{\mathrm{c}}$ & 4 & .000 \\
\hline b13cs & It's ok to guess if you don't know a word in English. & 123 & 3.5772 & 1.29948 & $24.033^{\mathrm{d}}$ & 4 & .000 \\
\hline b16cs & It is important to repeat and practice a lot. & 125 & 4.8720 & .45748 & $2.928 \mathrm{E} 2^{\mathrm{e}}$ & 3 & .000 \\
\hline b19cs & I feel shy speaking English with other people. & 122 & 3.0164 & 1.50472 & $2.754^{\mathrm{a}}$ & 4 & .600 \\
\hline b20cs & $\begin{array}{l}\text { If beginning students are allowed to make mistakes in } \\
\text { English it will be difficult for them to speak correctly } \\
\text { later on. }\end{array}$ & 119 & 3.5294 & 1.26775 & $19.950^{\mathrm{f}}$ & 4 & .001 \\
\hline b24cs & $\begin{array}{l}\text { It is important to practice with cassettes/ tapes, or CD } \\
\text { ROMs. }\end{array}$ & 123 & 4.4146 & .97448 & $1.654 \mathrm{E} 2^{\mathrm{d}}$ & 4 & .000 \\
\hline
\end{tabular}

\section{Motivation and expectations}

In order to investigate the views of participants on the items expected to examine the motivation and expectations of participants on learning, a chi-square analysis was performed. The results, appeared in Table 10, shows that the participants have more agreement on items b18, b22, b27, b29 and b30. The participants' view on items b18, b22, and b29 are more homogenous. The chi-square analysis shows that there is a significant difference among the responses of participants to these items.

TABLE 10:

DESCRIPTIVE ANALYSIS OF ITEMS EXAMINING MOTIVATION AND EXPECTATIONS

\begin{tabular}{|c|c|c|c|c|c|c|c|}
\hline Items & Content & $\mathbf{N}$ & Mean & $\begin{array}{l}\text { Std. } \\
\text { Deviation }\end{array}$ & $\begin{array}{l}\text { Chi- } \\
\text { Square }\end{array}$ & df & $\begin{array}{l}\text { Asymp. } \\
\text { Sig. }\end{array}$ \\
\hline b4mot & I believe I will learn to speak English very well. & 124 & 3.7258 & 1.00680 & $63.097^{\mathrm{a}}$ & 4 & .000 \\
\hline b18mot & $\begin{array}{l}\text { People in my country feel that it is important to speak } \\
\text { English. }\end{array}$ & 125 & 4.1120 & .98551 & $81.280^{\mathrm{b}}$ & 4 & .000 \\
\hline b22mot & $\begin{array}{l}\text { I would like to learn English so that I can get to know } \\
\text { English people better. }\end{array}$ & 123 & 4.5041 & .92660 & $1.974 \mathrm{E} 2^{\mathrm{c}}$ & 4 & .000 \\
\hline b27mot & $\begin{array}{l}\text { If I learn to speak English very well. I will have better job } \\
\text { opportunities. }\end{array}$ & 121 & 4.3140 & 1.02496 & $1.314 \mathrm{E} 2^{\mathrm{d}}$ & 4 & .000 \\
\hline b29mot & I want to learn to speak English very well. & 120 & 4.5583 & .81782 & $2.024 \mathrm{E} 2^{\mathrm{e}}$ & 4 & .000 \\
\hline b30mot & I would like to have English friends. & 120 & 4.0583 & 1.10989 & $73.083^{\mathrm{e}}$ & 4 & .000 \\
\hline
\end{tabular}




\section{Within Subject Difference}

In order to examine the differences among the views of participants on the five sections of belief questionnaire, a repeated measure ANOVA was performed. The Multivariate tests within subject effect reveals that there is a significant difference $(\mathrm{F}(4,90)=18.87, \mathrm{p}=0.000)$ in how these sections are rated by the participants. The Tests of within Subject Effects, as appeared in Table 11 , shows that there is a significant difference $(\mathrm{F}(3.64,321.38)=16.22$, $\mathrm{p}=0.000)$ among the responses of the participants on these sections.

TABLE 11:

TESTS OF WITHIN-SUBJECTS EFFECTS FOR FIVE SECTIONS OF BELIEF QUESTIONNAIRE

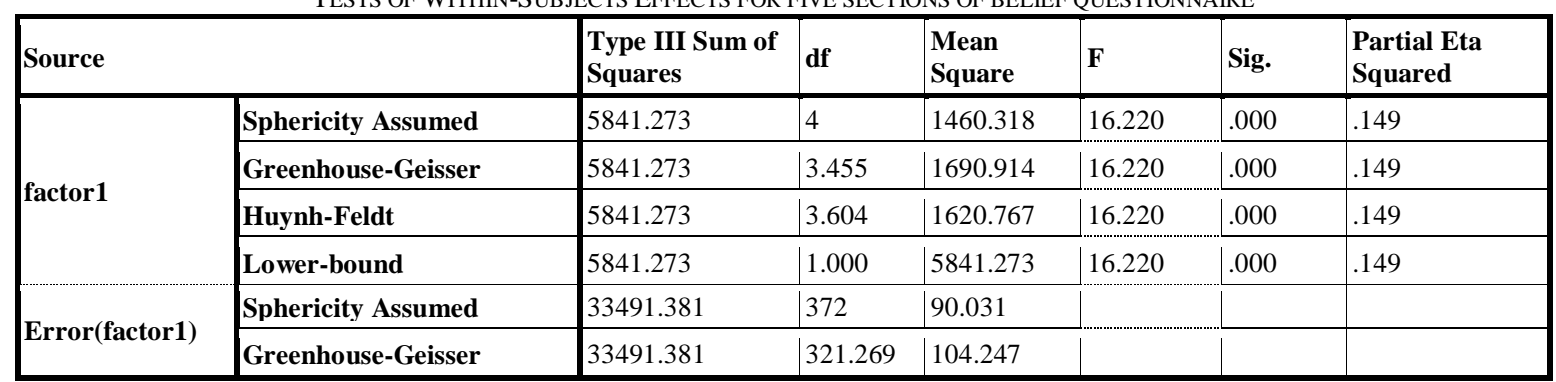

\section{DiSCUSSION AND CONCLUSIONS}

The current study is the first research attempt to investigate the beliefs of non-English majors with different English proficiency levels about language learning. The first research question in the present study, as stated in method, explores the relationship between English language proficiency and learners' beliefs about English language learning. Considering the performance of four groups of participants on Michigan test and belief questionnaire, and based on data analysis results, it was found that there is a significant difference between the level of language proficiency and motivation. There is no significant difference among the levels of language proficiency and the other sections of belief questionnaire.

In addition, the tests of within subject effects show that there is a significant difference among the responses of the participants on the five sections of belief questionnaire.

The second research question of the current study investigates whether or not the field of study influences the beliefs of non-English majors in English language learning. Based on data analysis results, there is a significant difference among the aptitude of the four groups of participants. The students of the four fields of study (biology, geography, accounting and science) did not express different views concerning difficulty, nature, communication strategies and motivation.

The third research question of this study examines the difference between the learning belief of males and females who are studying in biology, geography, accounting and science. The results show that there is no significant difference among the belief of students in different fields of study on these five sections of belief questionnaire. There is also no significant difference between males and females. The interaction between male and female students in these disciplines shows that these are significantly different in the aptitude and the nature of language learning.

\section{REFERENCES}

[1] Bernat, E. (2006, June). Assessing EAP learners' beliefs about language learning in the Australian context. Asian EFL Journal, $8 / 2,1-19$.

[2] Bernat, E., \& Gvozdenko, I. (2005, June). Beliefs about language learning: Current knowledge, pedagogical implications and new research directions. TESL-EJ, 9(1), 1-29.

[3] Bernat, E., \& Lloyd, R. (2007). Exploring the gender effect on EFL learners' beliefs about language learning. Australian Journal of Educational \& Developmental Psychology, 7, 79-91.

[4] Chiou, B. (2006). An investigation of English language learning beliefs held by continuous education program students. American Review of China Studies, 60(12), 96-218.

[5] Cotterall, S. (1995). Readiness for autonomy: Investigating learner beliefs. System, 23/2, 195-205.

[6] Cotterall, S. (1999). Key variables in language learning: what do learners believe about them? System, 27/4, 493-513.

[7] Ellis, R. (2008, December). Learner beliefs and language learning. Asian EFL Journal, 10/4, 63-58.

[8] Hurd, S. (2003). Learner difference in independent language learning contexts. Retrieved October 7, 2008, from: http://www.llas.ac.uk/resources/gpg/1573

[9] Lambert, C.P. (2001). The viability of learners' beliefs and opinions as input for second language course design. RELC Journal, $32(1), 1-15$

[10] Mantle-Bromley, C. (1995). Positive attitudes and realistic beliefs: Links to proficiency. Modern Language Journal, 79(3), 372-386.

[11] Mokhtari, A. (2007). Language learning strategies and beliefs about language learning: A study of University students of Persian in the United States. Unpublished doctoral dissertation, University of Texas, Austin. Retrieved June 17, 2008, from: http://repositories.lib.utexas.edu/bitstream/handle/2152/3373/mokhtaria63798.pdf?sequence=2 
[12] Nikitina, L., \& Furuoka, F. (2006). Re-examining Horwitz's Beliefs about Language Learning Inventory (BALLI) in the Malaysian context. Electronic Journal of Foreign Language Teaching, 3(2), 209-219. Retrieved July 5, 2008, from: http://eflt.nus.edu.sg/v3n22006/nikitina.htm

[13] Nikitina, L., \& Furuoka, F. (2007). Beliefs about Language Learning: A Comparison between Novice and Intermediate Level students learning Russian at a Malaysian University. Linguistics Journal, 2 (1), 7-27.

[14] Oz, H. (2007). Understanding metacognitive knowledge of Turkish EFL students in secondary education. Novitas-ROYAL, 1(2), 53-83.

[15] Peacock, M. (2007, April). Beliefs about language learning and their relationship to proficiency. International Journal of Applied Linguistics, 9/2, 247-263.

[16] Rieley, P. A. (2009). Shifts in beliefs about second language learning. RELC Journal, 40(1), 102-124. Abstract retrieved September 5, 2009, from: http://rel.sagepub.com/cgi/content/abstract/40/1/102

[17] Sakui, K. \& Gaies, S.J. (1999). Investigating Japanese learners' beliefs about language learning. System, 27/4, 473-492.

[18] Tercanlioglu, L. (2005). Pre-service EFL teachers' beliefs about foreign language learning and how they relate to gender. Electronic Journal of Research in Educational Psychology, 3(5), 145-162.

[19] Zhang, C., \& Zhou, Z. (2005, April). A study of the relationship of language learners' beliefs and autonomous learning. USChina Foreign Language, 3(4), 64-68.

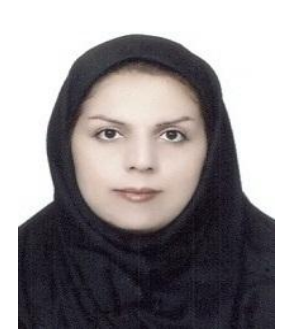

Hadiseh Bagherzadeh was born in Maku, Iran in 1981. She has extensive experience in English language teaching and is a member of Teaching English Language and Literature Society of Iran (TELLSI). She received her Master of Arts in Teaching English Language as a Foreign Language (TEFL) from Tehran University in Iran. She currently teaches English courses in different Universities of Tabriz, Iran. Her main interest includes students centered learning, particularly belief and motivation, teacher education, teacher motivation, learned-centered instruction and fairness in language testing. 